\title{
Optimal Irrigation Scheduling for Pepper (Capsicum annuum L.) at Gidara Condition, Central Rift Valley of Ethiopia
}

\author{
Gobena Dirirsa, Tilahun Hordofa, Ketema Tezera, Abera Tesfaye and Tatek Wondimu \\ Ethiopian Institute of Agricultural Research, Melkassa Agricultural Research Center \\ P.O.Box 436, Adama, Ethiopia
}

\begin{abstract}
The wise use of irrigation water relies on understanding the exact crop water demand and its application which help to boost agricultural water productivity. Proper irrigation scheduling comprises crop water demand and the rifling frequency of the required water amount. Therefore, this activity was aimed at determining the optimal irrigation regime for pepper. The trial was carried out during 2016 and 2017 to determine the optimal irrigation regime of Pepper (Mareko Fana variety) at Gidara trial site of Melkassa Agricultural Research under five soil moisture depletion levels at which the next irrigation is given: 60\% ASMDL, 80\% ASMDL, 100\% ASMDL, $120 \%$ ASMDL and 140\% ASMDL). The allowable soil moisture depletion level (100\% ASMDL) was scheduled to be refilled when $30 \%$ of the total available soil moisture was depleted. The result revealed that there was significant difference in plant height, yield and water productivity among treatments at 5\% level of significance. The maximum yield and water productivity were observed in 60\% ASMDL treatment. Using depletion levels of $60 \%$ and $80 \%$ of the recommended soil moisture depletion levels has increased the water productivity significantly. Hence, as much as the total water to be applied throughout the growth period is similar it is better to irrigate pepper frequently with smaller amount.
\end{abstract}

Keywords: Allowable soil moisture depletion level, Irrigation interval, Irrigation regime, Pepper, Water productivity

DOI: $10.7176 / \mathrm{JEES} / 12-1-02$

Publication date: January $31^{\text {st }} 2022$

\section{Introduction}

Irrigation basically is the controlled application of water to crops in right amount at the right time reducing water loss. Irrigation scheduling is a systematic method by which a producer can decide on when to irrigate and how much water to apply. The goal of an effective scheduling program is to supply the plants with sufficient water while minimizing loss to deep percolation or runoff. Irrigation scheduling depends on soil, crop, atmospheric, irrigation system and operational factors. Irrigation scheduling determines the agronomic and economic benefits of farms. Hence, irrigation scheduling is important for developing best management practices for irrigated areas (Ali et al., 2011). The irrigation water is applied to the cultivation according to predetermined schedules based upon the monitoring of the soil water status and the crop water requirements.

Proper irrigation scheduling needs a sound basis for making irrigation decisions. The level of sophistication for decision making varies from personal experience to techniques based on expensive computer-aided instruments that can assess soil, water and atmospheric parameters. The type of soil and climatic conditions significantly affect the main practical aspects of irrigation, which are the determination of how much water should be applied and when it should be applied to a given crop.

Proper irrigation scheduling which depends on evapotranspiration of crops improves water use efficiency of crops (Tyagi et al., 2000). For the current study, though irrigation has long been practiced in Ethiopia under different farm levels, the management practice is not efficient. There is lack of information and knowledge on proper irrigation water management and agronomic management practices although irrigation farms are expanding in the country.

Pepper (Capsicum annuum L.) is one of the vegetable crops commonly grown in Ethiopia, mainly under rainfed agriculture. In Ethiopia rainfall distribution is highly erratic both spatially and temporarily. Sensitivity of pepper to low soil moisture along with the unpredictability of rainfall in the country leads to the use of irrigation for its production. Moreover, for better irrigation management understanding of optimum irrigation regime is very important for pepper production so as to optimize yield and water use efficiency.

Nevertheless, there is no exact information for pepper concerning its optimum moisture depletion level for irrigation specific to the study area. Thus, this study was aimed at investigating the effects of different soil moisture depletion levels for irrigation and then to determine the irrigation depth and frequency. 


\section{Materials and Methods}

\subsection{Study area}

The field experiment was conducted at Gidara experimental site, which is a Sub-center of Melkassa Agricultural Research Center. The site is located in Oromia region, East Shoa zone in Fentale woreda. The site is geographically located at $08^{0} 44^{\prime} 55^{\prime \prime} \mathrm{N}$ latitude and $39^{\circ} 47^{\prime} 49^{\prime \prime} \mathrm{E}$ longitude with altitude of $1112 \mathrm{~m}$ above sea level.

The long-term weather data collected from the nearby Metrological station revealed that the maximum and minimum monthly average temperature of the sub center is $31.70^{\circ} \mathrm{C}$ and $16.80^{\circ} \mathrm{C}$, respectively. The long-term rainfall of the area is $615 \mathrm{~mm}$ with main rainy season from July to September when $57 \%$ of the annual rain fall is received. The climate water balance of the study area (Figure 1) shows that there is a need for irrigation water for almost the year round except for the months July to September.

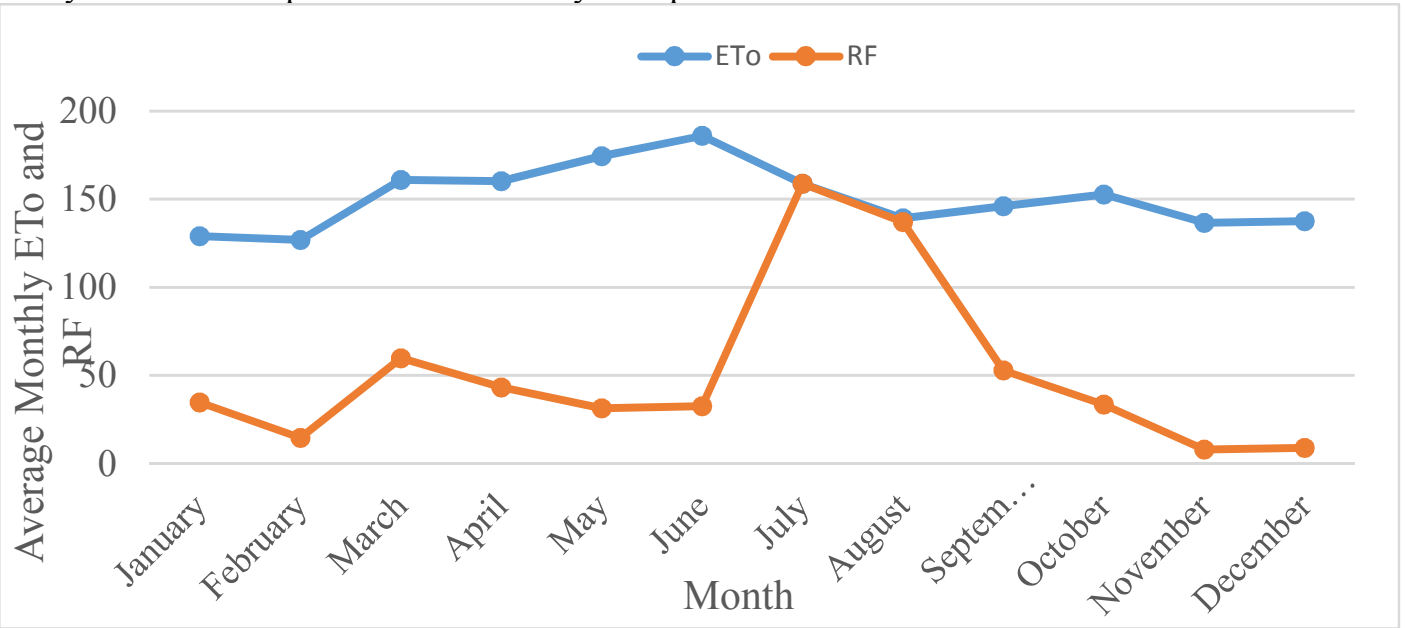

Figure 1. Climate water balance (ETo-Evapotranspiration vs RF-rainfall)

The soil texture of the study area is sandy loam with bulk density of $1.17 \mathrm{gm} / \mathrm{cm}^{3}$. The soil moisture constants, such as field capacity (FC) and permanent wilting point (PWP) are $245 \mathrm{~mm} / \mathrm{m}$ and $166.6 \mathrm{~mm} / \mathrm{m}$, respectively. Moreover, the electrical conductivity and organic matter content of the soil as determined by laboratory analysis were $19.8 \mathrm{mS} / \mathrm{m}$ and $2.17 \%$, respectively.

\subsection{Experimental Design and Treatment Combinations}

Randomized complete block design (RCBD) with three replications was used for the study. The experiment included five soil water depletion levels (SMDL) as a treatment, the five level of SMDL are (60\% of ASMDL, $80 \%$ of ASMDL, $100 \%$ of ASMDL, $120 \%$ of ASMDL and $140 \%$ of ASMDL). For pepper crop allowable soil moisture depletion level (ASMDL) as indicated by Doorenbos. and Kassam ( 1979) is 0.3, hence, for the other treatments the soil moisture depletion levels were calculated based on their percent proportion (Table 1).

Table 1. Treatment combinations

\begin{tabular}{ccc}
\hline Treatment* & Description & $\begin{array}{c}\% \text { depletion of total available water } \\
\text { before next irrigation }\end{array}$ \\
\hline SMDL 1 & $60 \%$ of ASMDL & $42 \%$ \\
SMDL 2 & $80 \%$ of ASMDL & $36 \%$ \\
SMDL 3 & ASMDL* (control) & $30 \%$ \\
SMDL 4 & $120 \%$ of ASMDL & $24 \%$ \\
SMDL 5 & $140 \%$ of ASMD & $18 \%$ \\
\hline
\end{tabular}

*ASMDL (allowable soil moisture depletion level)

\subsection{Agronomic management practices}

Pepper (Capsicum annuum L.), Mareko Fana variety was sown on a $1 \mathrm{~m}$ by $5 \mathrm{~m}$ bed in December each year and after about 30days the seedlings were transplanted in January. The experimental plot dimensions used were $4.5 \mathrm{~m}$ wide and $5 \mathrm{~m}$ long with $0.75 \mathrm{~m}$ row spacing and $0.30 \mathrm{~m}$ plant spacing. The number of planting rows in each plot were five of which the middle three were sampling rows and the other two are guard rows. All agronomic practices were kept normal and performed at the appropriate time. The experimental treatments were started after two irrigations were given for establishment. It was harvested after about 125 days from transplanting.

\subsection{Irrigation management}

Depth of irrigation water applied was estimated from daily climate data. Daily climatic data (maximum and minimum temperatures, humidity, wind speed and actual sunshine hours), and geographical information 
(coordinates and altitude of the location) were used to calculate ETo using CROPWAT 8 model following FAO Penman-Montieth equation (Allen et al., 1998) (equation 1). And daily Evapotranspiration (ETc) was estimated by multiplying the ETo by the crop coefficient (Kc) (equation 2). Thus, the amount of irrigation water applied at each irrigation time was determined considering ETc, crop growth stage (rooting depth) and soil data (water holding capacity) as well as precipitation data. The estimation was on daily water balance basis as indicated in Allen et al., (1998).

$$
\mathrm{ET}_{\mathrm{o}}=\frac{0.408 \Delta\left(\mathrm{R}_{\mathrm{n}}-\mathrm{G}\right)+\gamma \frac{900}{\mathrm{~T}+273} \mathrm{u}_{2}\left(\mathrm{e}_{\mathrm{s}}-\mathrm{e}_{\mathrm{a}}\right)}{\Delta+\gamma\left(1+0.34 \mathrm{u}_{2}\right)}
$$

Equation 1

Where: $\Delta$ is the slope of the curve of saturation vapour pressure in $\mathrm{kPa}^{\circ} \mathrm{C}^{-1}$ to the mean air temperature $\mathrm{T} ; \mathrm{Rn}$ is the net radiation received over the surface or field being studied in $\mathrm{MJm}^{-2}$ day $^{-1}$, which is comprised by the short wave solar radiation $R_{n s}$ minus the net long wave radiation $R_{n l}$ both in $M J / m^{2}$ day; $G$ is the heat flow or thermal flow from the floor in cal $/ \mathrm{m}^{2}, \gamma$ is the psychrometric constant in $\mathrm{kPa}^{\circ} \mathrm{C}^{-1} ; \mathrm{U}_{2}$ is the wind speed at $2 \mathrm{~m} \mathrm{high} \mathrm{in} \mathrm{m} / \mathrm{s}$; and $\left(e_{s}-e_{a}\right)$ is the deficit of vapour pressure in $\mathrm{kPa}$, which is determined by the difference between the vapour pressure saturation of the air $\mathrm{e}_{\mathrm{s}}$ at temperature $\mathrm{T}$ minus the vapour pressure of the air mass $\mathrm{e}_{\mathrm{a}}$ at a temperature $\mathrm{T}$.

$\mathrm{ETc}=\mathrm{Kc} \times \mathrm{ETo}$ Equation 2

Where, $\mathrm{Kc}$ is crop coefficient (fraction); ETc is crop evapotranspiration (mm/day), and ETo is reference evapotranspiration ( $\mathrm{mm} /$ day).

For each experimental treatment the amount of water applied at each irrigation interval was determined following the respective soil moisture depletion level of each treatment. Accordingly, the average irrigation intervals and depth of irrigation used for treatment at each growth stage is indicated in table 2.

Table 2. Average irrigation interval and depth of application per interval

\begin{tabular}{ccccccccccc} 
& \multicolumn{2}{c}{$60 \%$ of } & \multicolumn{2}{c}{$80 \%$ of } & \multicolumn{2}{c}{$100 \%$ of } & \multicolumn{2}{c}{$120 \%$ of } & \multicolumn{2}{c}{$140 \%$ of } \\
& ASMDL & \multicolumn{2}{c}{ ASMDL } & \multicolumn{2}{c}{ ASMDL } & \multicolumn{2}{c}{ ASMDL } & \multicolumn{2}{c}{ ASMDL } \\
\hline Growth stage & $\mathrm{T}$ & $\mathrm{D}$ & $\mathrm{T}$ & $\mathrm{D}$ & $\mathrm{T}$ & $\mathrm{D}$ & $\mathrm{T}$ & $\mathrm{D}$ & $\mathrm{T}$ & $\mathrm{D}$ \\
Initial & 3 & 10.5 & 4 & 14.4 & 5 & 16.4 & 6 & 19.6 & 7 & 23.0 \\
Development & 4 & 19.0 & 6 & 26.2 & 7 & 33.9 & 9 & 38.6 & 11 & 48.7 \\
Mid & 4 & 23.4 & 5 & 28.7 & 6 & 35.0 & 7 & 40.8 & 8 & 45.8 \\
Maturity & 4 & 23.8 & 5 & 30.0 & 7 & 38.7 & 8 & 44.2 & 9 & 53.5 \\
\hline
\end{tabular}

$\mathrm{D}=$ Irrigation Depth in $\mathrm{mm}, \mathrm{T}=$ Irrigation Interval in days

Irrigation water was taken to the experimental plots by an open channel and water measurement was conducted using Parshall flume of 3-inch throat width (Kandiah, 1981). Measured amount of water was given at each irrigation day. Field application efficiency of $60 \%$ was used in computing the gross irrigation as indicated by Bakker et al. (1999). They indicated application efficiency of $45 \%-60 \%$ for furrow irrigation method, As the trial was conducted in research sites by researchers the maximum value of $60 \%$ was considered in this study. Time is then recorded with a stopwatch to control the amount of water applied to each plot. Accordingly, the time required to deliver the desired depth of water into each plot was calculated using the following equation (equation 3):

$$
\begin{array}{ll}
\mathrm{t}=\frac{\mathrm{D}_{\mathrm{g}} \times \mathrm{A}}{60 \times \mathrm{q}} & \text { Equation } 3
\end{array}
$$

Where: $\mathrm{Ig}=$ gross depth of water applied $(\mathrm{mm}), \mathrm{t}=$ application time $(\mathrm{min}), \mathrm{A}=$ plot area, $\mathrm{q}=$ flow rate $(\mathrm{l} / \mathrm{s})$ at specific Parshall flume head and 60 (sixty) is unit adjusting figure.

\subsection{Water productivity}

Water productivity (WP) is estimated as a ratio of yield to the total Evapotranspitation (ETc) throughout the growing season and it is calculated as indicated in equation 4 (Zwart and Bastiaanssen, 2004; Molden, 2010).

$$
\begin{array}{ll}
W P=\frac{Y}{E T_{c}} & \text { Equation } 4
\end{array}
$$

Where, WP is water productivity $\left(\mathrm{kg} / \mathrm{m}^{3}\right), \mathrm{Y}$ is crop yield $(\mathrm{kg} / \mathrm{ha})$ and ET is the seasonal crop water consumption by evapotranspiration $\left(\mathrm{m}^{3} / \mathrm{ha}\right)$.

\subsection{Data analysis}

The collected data were statistically analyzed using statistical analysis system (SAS) software version 9.0 using the general linear programming procedure (GLM). Mean separation was employed using least significant difference (LSD) at 5\% probability level to compare the difference among the treatment means.

\section{Results and discussion}

3.1 Effect of soil moisture depletion on pepper yield, plant height and water productivity

To investigate the effect of different soil moisture depletion levels on plant height, the height of five randomly 
selected plant was measured from ground level to apex stem. The result revealed that plant height was significantly $(\mathrm{P}<0.05)$ affected as a result of irrigation application at different soil moisture depletion levels. Higher plant height was obtained from the frequently irrigated pepper $(60 \%$ \& $80 \%$ ASMDL). Lower plant height was observed for pepper irrigated at greater soil moisture depletion level, which have higher irrigation interval as shown in Table 3. Similar result was obtained by Juan and Alejandro (2016), which indicates that frequent irrigation of Piquin Pepper favors plant growth and less frequent irrigation reduces plant growth.

The effect of soil moisture depletion level on pepper yield is analyzed and presented in Table 3 . The analysis result of the two-years and the over year combined data shows a significant $(\mathrm{P}<0.05)$ difference on pepper yield as affected by the different soil moisture depletion levels. Accordingly, the highest yield of 19.05t/ha was recorded from the frequently irrigated plot and the lowest yield $(15.41 \mathrm{t} / \mathrm{ha})$ was recorded from the treatment irrigated with wider interval. Similarly, Juan and Alejandro (2016) observed an increase in yield with an increase in irrigation frequency and vice versa.

The analysis result of water productivity is depicted in Table 3 . Significantly $(\mathrm{P}<0.05)$ higher water productivity $\left(3.19 \mathrm{~kg} / \mathrm{m}^{3}\right)$ was obtained under $60 \%$ ASMDL with no significant difference with $80 \%$ ASMDL treatment; while the lowest $\left(2.74 \mathrm{~kg} / \mathrm{m}^{3}\right)$ was obtained under $140 \%$ ASMDL. Similarly, Juan and Alejandro (2016) demonstrated that higher frequency favors water productivity of Piquin Pepper.

Table 3. Pepper Yield, Plant Height and Water Productivity as Affected by Irrigation Regime

\begin{tabular}{lccc|ccc|ccc}
\hline Treatments & \multicolumn{3}{c|}{ Year 1 } & \multicolumn{3}{c|}{ Year 2 } & \multicolumn{3}{c}{ Combined result } \\
\hline & $\begin{array}{c}\text { Plant } \\
\text { Height } \\
(\mathrm{cm})\end{array}$ & $\begin{array}{c}\text { Yield } \\
(\mathrm{Qt} / \mathrm{ha})\end{array}$ & $\begin{array}{c}\text { WP } \\
\left(\mathrm{Kg} / \mathrm{m}^{3}\right)\end{array}$ & $\begin{array}{c}\text { Plant } \\
\text { Height } \\
(\mathrm{cm})\end{array}$ & $\begin{array}{c}\text { Yield } \\
(\mathrm{Qt} / \mathrm{ha})\end{array}$ & $\begin{array}{c}\text { WP } \\
\left(\mathrm{Kg} / \mathrm{m}^{3}\right)\end{array}$ & $\begin{array}{c}\text { Plant } \\
\text { Height } \\
(\mathrm{cm})\end{array}$ & $\begin{array}{c}\text { Yield } \\
(\mathrm{Qt} / \mathrm{ha})\end{array}$ & $\begin{array}{c}\text { WP } \\
\left(\mathrm{Kg} / \mathrm{m}^{3}\right)\end{array}$ \\
\hline SMDL 1 & $53.80^{\mathrm{a}}$ & $18.93^{\mathrm{a}}$ & $3.17^{\mathrm{a}}$ & $53.53^{\mathrm{a}}$ & $19.17^{\mathrm{a}}$ & $3.20^{\mathrm{a}}$ & $53.67^{\mathrm{a}}$ & $19.05^{\mathrm{a}}$ & $3.19^{\mathrm{a}}$ \\
SMDL 2 & $53.67^{\mathrm{a}}$ & $18.42^{\mathrm{a}}$ & $3.08^{\mathrm{a}}$ & $52.27^{\mathrm{a}}$ & $18.40^{\mathrm{a}}$ & $3.08^{\mathrm{a}}$ & $51.97^{\mathrm{a}}$ & $18.41^{\mathrm{ab}}$ & $3.07^{\mathrm{b}}$ \\
SMDL 3 & $47.80^{\mathrm{b}}$ & $16.53^{\mathrm{b}}$ & $2.76^{\mathrm{b}}$ & $48.67^{\mathrm{ab}}$ & $16.95^{\mathrm{ab}}$ & $2.83^{\mathrm{ab}}$ & $48.23^{\mathrm{b}}$ & $16.74^{\mathrm{bc}}$ & $2.80^{\mathrm{bc}}$ \\
SMDL 4 & $46.73^{\mathrm{b}}$ & $16.22^{\mathrm{b}}$ & $2.71^{\mathrm{b}}$ & $46.93^{\mathrm{b}}$ & $15.42^{\mathrm{b}}$ & $2.58^{\mathrm{b}}$ & $46.83^{\mathrm{b}}$ & $15.82^{\mathrm{c}}$ & $2.75^{\mathrm{c}}$ \\
SMDL 5 & $45.27^{\mathrm{b}}$ & $16.13^{\mathrm{b}}$ & $2.70^{\mathrm{b}}$ & $45.00^{\mathrm{b}}$ & $14.68^{\mathrm{b}}$ & $2.45^{\mathrm{b}}$ & $45.13^{\mathrm{b}}$ & $15.41^{\mathrm{c}}$ & $2.74^{\mathrm{c}}$ \\
CV (\%) & 4.17 & 4.82 & 4.76 & 5.35 & 8.84 & 8.83 & 6.13 & 9.13 & 9.11 \\
LSD $_{0.05}$ & 3.85 & 1.56 & 0.25 & 4.97 & 2.82 & 0.47 & 3.65 & 1.89 & 0.32 \\
\hline
\end{tabular}

*Means followed by different superscripts are statistically different, SMDL: soil moisture depletion level, WP: water productivity

\section{Conclusion and recommendation}

The results of the experiment depicted that managing the soil moisture content above the allowable depletion level like $60 \%$ ASMDL and $80 \%$ ASMDL was better than the recommended allowable depletion and the other lower levels. Thus, irrigating pepper in a shorter frequency with smaller amount enhance pepper yield and water productivity than irrigating with wider interval but larger amount. Therefore, for higher yield and maximum water productivity it could be better to irrigate pepper frequently.

\section{Acknowledgement}

The authors are grateful to Ethiopian Institute of Agricultural Research, for providing funds for the experiment and technical support. They are thankful to Selman Kiyar, Tayech Bekele and Fantu Belay for their technical assistance in the field experimentation. They highly acknowledge all staff members of Melkassa Agricultural Research Center, particularly Irrigation and Drainage Research Team members for their kind cooperation during field experimentation and data collection.

\section{References}

Ali M. H., Paul H. and Haque, M. R. (2011). Estimation of evapotranspiration using a simulation model. J. Bangladesh Agril. Univ. 9(2): 257-266.

Allen R G; Pereira L S; Raes D and Smith M (1998). Crop Evapotranspiration. Guidelines for Computing Crop Water Requirements. FAO Irrigation \& Drainage Paper 56. Food and Agricultural Organization of the United Nations, Rome, Italy 300 pp.

Bakker, DM; Raine SR and Robertson, MJ. (1999). A preliminary Investigation of Alternate Furrow Irrigation for Sugar Cane Production. http://www.usq.edu.au/users/raine/index fiels/ASSCT 97.Bakker et al., pdf.

Doorenbos, J. and Kassam A.H. (1979). Yield response to water. FAO Irrigation Drainage Paper No. 33. FAO, Rome, Italy.

Juan I. V. and Alejandro G. O. (2016). Effect of irrigation frequency and shade levels on vegetative growth, yield and fruit quality of Piquin Pepper (Capsicum annum L. var. glabriusculum). Hortscience 51(5): 573-579.

Kandiah, A. (1981). Guide for measurement of irrigation water using Parshall flumes and siphons: Technical bulletin № 1. Addis Ababa, Ethiopia. p. 2. 
Molden, D.; Oweis, T.; Steduto, P.; Bindraban, P.; Hanjra, M.A. and Kijne, J. (2010). Improving agricultural water productivity: Between optimism and caution. Agric. Water Manag. 97: 528-553.

Tyagi, N. K., Sharma, D. K.and Luthra, S. K. (2000) Determination of evapotranspiration and crop coefficients of rice and sunflower with lysimeter; Agricultural Water Management; 45:41-54.

Valipour, M., 2014. Pressure on renewable water resources by irrigation to 2060. Acta Advances in Agricultural Sciences 2(8):23-42.

Zwart, S.J. and Bastiaanssen, W.G.M., 2004. Review of measured crop water productivity values for irrigated wheat, rice, cotton and maize, Agricultural Water Management,69(2),115-133. 